The Agriculturists 7(1\&2): 96-104 (2009)

ISSN-1729-5211

A Scientific Journal of Krishi Foundation

\title{
Evaluation of Some Indigenous Plant Extracts for Suppressing Bipolaris sorokiniana in Wheat Seed
}

\author{
Rokshana Panna, F.M. Aminuzzaman, M. R. Islam ${ }^{*}$ and M. H. M. Borhannuddin Bhuyan \\ Department of Plant Pathology, Sher-e-Bangla Agricultural University, Dhaka, Bangladesh \\ *Corresponding author and Email: rafique642003@yahoo.com
}

\begin{abstract}
Studies were conducted in the Seed Pathology Laboratory, Department of Plant Pathology, Sher-eBangla Agricultural University to evaluate some indigenous plant extracts on the incidence of Bipolaris sorokiniana of wheat and seed germination. Seed treated with plant extracts reduced the incidence of Bipolaris sorokiniana. The lowest incidence was counted (12.33\%) in seeds treated with Burmuda grass extracts $(1: 2 \mathrm{~W} / \mathrm{v})$. While the highest seed germination $(99.60 \%)$ was recorded in seeds treated with this grass extract followed by $99.33 \%$ germination in seeds treated with Neem leaf extract $\left(1: 2^{\mathrm{W}} / \mathrm{v}\right), 98.00 \%$ with nut sedge grass rhizome extract $(1: 2 \mathrm{~W} / \mathrm{V}), 87.67 \%$ with Allamanda leaf extract $(1: 2 \mathrm{~W} / \mathrm{v})$. Comparatively the lowest incidence of Bipolaris sorokiniana $(14.00 \%)$ was observed in seeds treated with Neem leaf extracts $(1: 2 \mathrm{~W} / \mathrm{V})$ followed by $14.50 \%$ in seeds treated with Nut sedge grass rhizome extracts $(1: 2 \mathrm{~W} / \mathrm{v})$, Black cumin seed extracts (15.20\%) and Allamanda leaf extract (24.00\%).
\end{abstract}

Keywords: Seed sorting, plant extracts, black point, Bipolaris sorokiniana, wheat

\section{Introduction}

Wheat (Triticum aestivum L.) is the most important cereal crop in the world. About two third of the World's population use wheat as staple food (Majumder, 1991). It is the second most important grain crop in Bangladesh that plays a vital role in the national economy by reducing the volume of import of cereals (Razzaque et al., 1992). In spite of its importance, yield of the crop in Bangladesh is low in comparison to the other countries of the world, where average yield was estimated to be 2.69 t/ha (FAO, 1997). About 706.86 thousand hectares of land in Bangladesh is covered by wheat cultivation with the annual production of 1570 thousand tons (BBS, 2006). In wheat, 26 seed borne pathogens are reported to cause 14 seed borne diseases, among them leaf spot and black point caused by Bipolaris sorokiniana has become a serious concern in Bangladesh (Azhar et al., 1972; Fakir, 1988). The most economic method for controlling the disease is to cultivate resistant variety (Hossain and Azad, 1992). The second most acceptable method for controlling this disease is to sow pathogen free seeds. On the other hand, chemical treatments are most effective but expensive for controlling the disease, at the same time continuous use of chemicals pollutes the environment and develops tolerance against pathogens. In this aspect seed treatment with botanicals may be a safe option in controlling seed borne pathogens. Uses of plant extracts in controlling pathogens are now found to be promising and successful against certain fungal pathogens (Assadi and Behroozin, 1987; Miah et al., 1990; Fakir and Khan, 1992; Suratuzzaman, 1995; Hossain et al. 1997). Hossain and Schlosser (1993) reported sound fungicidal effect of Neem (Azadirachta indica) extracts against Bipolaris sorokiniana. Now a 
days scientists are giving more emphasis on sustainable technology for environment friendly agriculture. So, it has become necessary to find out ecologically sound, economically viable, culturally appropriate and socially adoptable technology. Considering the above facts the present investigation was undertaken to evaluate some indigenous plant extracts for suppressing Bipolaris sorokiniana of wheat and to observe the success in seed germination.

\section{Materials and Methods}

The experiment was conducted at the Seed Pathology Laboratory, Department of Plant Pathology, Sher-e-Bangla Agricultural University, Dhaka, Bangladesh from January to September, 2007. The experiment was laid out in Completely Randomized Design (CRD). Four hundred (400) seeds were tested for each treatment. The seed health testing was done by Blotter method (ISTA, 1999). Data was recorded on germination percentage and percent seed affected by Bipolaris sorokiniana. Five different plant extracts of Allamanda leaf, Neem leaf, Nut sedge grass Rhizome, Burmuda grass and Black cumin seed were tested against Bipolaris sorokiniana through five sets of experiments. About $6 \mathrm{~kg}$ seed sample of wheat cv. Kanchan was collect from a farmer of Gazipur district and used in this study. Apparently healthy looking seeds were separated from farmer's seed by manual seed sorting by eliminating inert matter, varietal mixture, seeds of other crops and weed seeds, crop residues and black pointed seeds.

Botanicals were collected locally and their extracts were prepared by using the method of Hossain et al. (2005). For preparation of extracts, collected leaves, seeds and rhizomes were weighed and then washed in water. After washing the big leaves and rhizomes were cut into pieces. For getting extract, weighed plant parts were blended in an electric blender and then distilled water was added into the jug of the blender. For getting 1:2 ( $/ \mathrm{V} / \mathrm{v})$ ratios; $200 \mathrm{ml}$ of distilled water was added in $100 \mathrm{~g}$ plant parts. Similarly to get $1: 4(\mathrm{~W} / \mathrm{v}), 1: 6(\mathrm{~W} / \mathrm{v})$ ratios and 1:8 $(\mathrm{W} / \mathrm{V})$ ratios, 400, 600 and $800 \mathrm{ml}$ distilled water was added in $100 \mathrm{~g}$ plant parts respectively. Desired concentration of the botanicals used in the present experiment is shown in Table 1.

Seeds were treated by dipping method separately in different extracts. Four hundred (400) seeds were dipped in the solution for 1 hour. The treated seeds were then taken out of the extract and spread on blotting paper to remove excess moisture prior to placing them in the petridishes.

Table 1. The particulars of the botanicals used in the study along with their desired concentration.

\begin{tabular}{l|l|c|c}
\hline Common name & \multicolumn{1}{|c|}{ Scientific name } & Plant parts used & Concentration \\
\hline Allamanda & Allamanda cathartica & Leaf & $1: 2,1: 4,1: 6,1: 8\left({ }^{\mathrm{W}} / \mathrm{V}\right)$ \\
Neem & Azadirachta indica & Leaf & $1: 2,1: 4,1: 6,1: 8\left({ }^{\mathrm{W}} / \mathrm{V}\right)$ \\
Kalizira & Nigella sativa & Seed & $1: 2,1: 4,1: 6,1: 8\left({ }^{\mathrm{W}} / \mathrm{V}\right)$ \\
Burmuda grass (Durba) & Cynodon dectylon & Whole plant & $1: 2,1: 4,1: 6,1: 8\left({ }^{\mathrm{W}} / \mathrm{V}\right)$ \\
Nut sedge (Mutha) & Cyperus rotundus & Rhizome & $1: 2,1: 4,1: 6,1: 8\left({ }^{\mathrm{W}} / \mathrm{V}\right)$ \\
\hline
\end{tabular}


For seed health study, three layers of filter paper (Whatman Paper No. 1) soaked in sterilized water and was placed at the base of a plastic petridishes ( $9 \mathrm{~cm}$ diameter.) then 25 seeds were placed on filter paper maintaining equal distance among seeds and covered with the lid. The petridishes containing seeds were incubated at $25 \pm 1{ }^{\circ} \mathrm{C}$ for 7 days maintaining alternative $12: 12$ $\mathrm{hr}$ light and dark cycle in the laboratory. Time to time water was added to keep the filter paper moist. After 7 days of incubation the incubated seeds were examined under stereoscopic microscope in order to record the incidence of Bipolaris sorokiniana. Germination of the seeds was also recorded. Identification of Bipolaris sorokiniana under the stereoscopic microscope was confirmed by preparing temporary slides and examining under the compound microscope with the help of keys described in taxonomic books (Booth, 1971, Ellis 1971). Later on the pathogen was purified using hyphal tip culture method and grown on PDA media at $25 \pm 1^{\circ} \mathrm{C}$ for 2 weeks and identified.

The collected data on different parameters were analyzed statistically by using MSTAT-C package program. The means for all the treatments were compared by DMRT. The significance of differences among the means was calculated by LSD test.

\section{Results and Discussion}

\subsection{Evaluation of Allamanda leaf extracts against Bipolaris sorokiniana}

The effects of Allamanda leaf extract treated apparently healthy and farmer's saved wheat seed on germination and incidence of Bipolaris sorokiniana are presented in Table 2. Germination (\%) of farmer's seed ranged from $76.50 \%$ to $82.50 \%$ treated with different doses of Allamanda leaf extract. The highest seed germination $(82.50 \%)$ was recorded in $1: 4(\mathrm{~W} / \mathrm{V})$ concentration of Allamanda leaf extract and the lowest $(76.50 \%)$ in untreated seeds (control). Germination percent of apparently healthy seeds was always found to be higher over farmer's seed. The highest germination $(87.67 \%)$ of apparently healthy seeds was recorded in 1:4 $(\mathrm{W} / \mathrm{v})$ concentrations of Allamanda leaf extract and the lowest $(78.00 \%)$ in control.
The incidence of Bipolaris sorokiniana on Allamanda treated wheat seeds was always higher in farmers saved seed over apparently healthy seeds (Table 2). The incidence of Bipolaris sorokiniana on farmer's saved seed ranged from $29.00 \%$ to $43.00 \%$ where the highest and lowest range was recorded in untreated control and 1:2( $(\mathrm{w} / \mathrm{v})$ concentration of Allamanda leaf extract, respectively. Similarly these two treatments resulted the highest $(39.43 \%)$ and the lowest $(24.00 \%)$ incidence of the fungi, respectively in apparently healthy seeds. It was found that apparently healthy seeds had comparatively lower incidence of the fungi over farmer's seed.

\subsection{Evaluation of Neem leaf extracts against Bipolaris sorokiniana}

The effects of Neem leaf extract treated apparently healthy and farmer's saved wheat seeds germination and incidence of Bipolaris sorokiniana are presented in Table 3. Germination percent in case of farmer's seed ranged from $76.50 \%$ to $93.00 \%$. The highest seed germination $(93.00 \%)$ was recorded in $1: 2$ $(\mathrm{W} / \mathrm{v})$ and 1:4 $(\mathrm{w} / \mathrm{v})$ concentration of Neem leaf extract and the lowest $(76.50 \%)$ in the control. Germination percent of apparently healthy seeds was found to be higher over farmers saved seed. The highest germination $(99.33 \%)$ of apparently healthy seeds of wheat was recorded in 1:2( $(\mathrm{w} / \mathrm{v})$ concentrations of Neem leaf extract and the lowest $(78.00 \%)$ in the control.

The incidence of Bipolaris sorokiniana on Neem leaf extract wheat seeds was always higher in farmers saved seed over apparently healthy seeds (Table 3). The incidence of Bipolaris sorokiniana on farmer's saved seed ranged from $16.50 \%$ to $43.00 \%$ in untreated control and $1: 2$ $(\mathrm{w} / \mathrm{v})$ concentration of Neem leaf extract. Similarly these two treatments resulted the highest $(39.43 \%)$ and the lowest (14.00\%) incidence of the fungus, respectively in apparently healthy seeds. It is found that apparently healthy seeds had comparatively lower incidence of the fungus over farmer's seed. 
Table 2. Effect of seed treatment with Allamanda leaf extract on germination and incidence of Bipolaris sorokiniana of wheat.

\begin{tabular}{|c|c|c|c|c|c|}
\hline \multirow{2}{*}{ Treatments } & \multirow{2}{*}{ Concentration } & \multicolumn{2}{|c|}{$\%$ Germination } & \multicolumn{2}{|c|}{$\begin{array}{c}\% \text { Incidence of } \\
\text { Bipolaris sorokiniana }\end{array}$} \\
\hline & & $\begin{array}{l}\text { Farmer's } \\
\text { saved } \\
\text { seed }\end{array}$ & $\begin{array}{l}\text { Apparently } \\
\text { healthy } \\
\text { seed }\end{array}$ & $\begin{array}{c}\text { Farmer's } \\
\text { saved } \\
\text { seed }\end{array}$ & $\begin{array}{l}\text { Apparently } \\
\text { healthy } \\
\text { seed }\end{array}$ \\
\hline Untreated control & & $76.50 \mathrm{c}$ & $78.00 \mathrm{~b}$ & $43.00 \mathrm{a}$ & $39.43 a$ \\
\hline Allamanda leaf extract & $1: 2(\mathrm{~W} / \mathrm{V})$ & $82.07 \mathrm{a}$ & $87.33 \mathrm{a}$ & $29.00 \mathrm{c}$ & $24.00 \mathrm{c}$ \\
\hline Allamanda leaf extract & $1: 4(\mathrm{w} / \mathrm{v})$ & $82.50 \mathrm{a}$ & $87.67 \mathrm{a}$ & $32.00 \mathrm{~b}$ & $27.33 b$ \\
\hline Allamanda leaf extract & $1: 6\left({ }^{\mathrm{W}} / \mathrm{v}\right)$ & $79.00 \mathrm{~b}$ & $87.17 \mathrm{a}$ & $32.50 \mathrm{~b}$ & $27.33 b$ \\
\hline Allamanda leaf extract & $1: 8(\mathrm{w} / \mathrm{V})$ & $77.00 \mathrm{c}$ & $86.17 \mathrm{a}$ & $34.00 \mathrm{~b}$ & $29.00 \mathrm{~b}$ \\
\hline $\operatorname{LSD}(\mathrm{P} \leq 0.05)$ & & 1.718 & 4.311 & 1.975 & 3.789 \\
\hline
\end{tabular}

Table 3. Effect of seed treatment with Neem leaf extract on germination and incidence of Bipolaris sorokiniana of wheat.

\begin{tabular}{|c|c|c|c|c|c|}
\hline \multirow{2}{*}{ Treatments } & \multirow{2}{*}{ Concentration } & \multicolumn{2}{|c|}{$\%$ Germination } & \multicolumn{2}{|c|}{$\begin{array}{c}\% \text { Incidence of } \\
\text { Bipolaris sorokiniana }\end{array}$} \\
\hline & & $\begin{array}{l}\text { Farmer's } \\
\text { saved } \\
\text { seed }\end{array}$ & $\begin{array}{c}\text { Apparently } \\
\text { healthy } \\
\text { Seed }\end{array}$ & $\begin{array}{c}\text { Farmer's } \\
\text { saved } \\
\text { seed }\end{array}$ & $\begin{array}{c}\text { Apparently } \\
\text { healthy } \\
\text { seed }\end{array}$ \\
\hline Untreated control & & $76.50 \mathrm{c}$ & $78.00 \mathrm{~d}$ & $43.00 \mathrm{a}$ & $39.43 \mathrm{a}$ \\
\hline Neem leaf Extract & $1: 2(\mathrm{w} / \mathrm{V})$ & $93.00 \mathrm{a}$ & $99.33 \mathrm{a}$ & $16.50 \mathrm{c}$ & $14.00 \mathrm{e}$ \\
\hline Neem leaf Extract & $1: 4\left({ }^{\mathrm{w}} / \mathrm{v}\right)$ & $93.00 \mathrm{a}$ & $99.00 \mathrm{a}$ & $17.50 \mathrm{c}$ & $15.50 \mathrm{~d}$ \\
\hline Neem leaf Extract & $1: 6\left({ }^{\mathrm{w}} / \mathrm{v}\right)$ & $92.00 \mathrm{a}$ & $97.00 \mathrm{~b}$ & $24.50 \mathrm{~b}$ & $20.33 b$ \\
\hline Neem leaf Extract & $1: 8(\mathrm{~W} / \mathrm{V})$ & $89.50 \mathrm{~b}$ & $90.00 \mathrm{c}$ & $26.00 \mathrm{~b}$ & $19.50 \mathrm{c}$ \\
\hline $\operatorname{LSD}(\mathrm{P} \leq 0.05)$ & & 2.139 & 1.566 & 2.063 & 0.367 \\
\hline
\end{tabular}




\subsection{Evaluation of Nut sedge grass rhizome extracts against Bipolaris sorokiniana}

The effects of Nut sedge grass rhizome extract treated apparently healthy and farmer's saved wheat seeds germination and incidence of Bipolaris sorokiniana are presented in Table 4. Germination (\%) of farmer's seeds treated with different doses of Nut sedge grass extract ranged from $76.50 \%$ to $93.00 \%$. The highest seed germination $(93.00 \%)$ was noted in $1: 2$ $(\mathrm{W} / \mathrm{V})$ concentration of Nut sedge grass extract and the lowest $(76.50 \%)$ in the control. Germination percent of apparently healthy seeds was found to be higher over farmer's seed. The highest germination $(98.00 \%)$ of apparently healthy seeds was observed in 1:2 $(\mathrm{w} / \mathrm{V})$ and 1:4 $(\mathrm{W} / \mathrm{V})$ concentrations of Nut sedge grass extract and the lowest $(78.00 \%)$ in the control.

The incidence of Bipolaris sorokiniana on Nut sedge grass extract treated wheat seeds was always higher in farmers saved seed over apparently healthy seeds (Table 3). The incidence of Bipolaris sorokiniana on farmer's saved seed ranged from $19.00 \%$ to $43.00 \%$ where the highest and lowest range was noted in untreated control and 1:2 $(\mathrm{w} / \mathrm{v})$ concentration of Nut sedge grass extract. Similarly these two treatments resulted the highest $(39.43 \%)$ and the lowest $(14.50 \%)$ incidence of the fungus, respectively in apparently healthy seeds. It was found that apparently healthy seeds had comparatively lower incidence of the fungus over farmer's seed.

\subsection{Evaluation of Burmuda grass extracts against Bipolaris sorokiniana}

The effects of Burmuda grass extract treated apparently healthy and farmer's saved wheat seeds germination and incidence of Bipolaris sorokiniana are present in Table 5. Germination (\%) of farmer's seed ranged from $76.50 \%$ to
$95.83 \%$. The highest seed germination $(95.83 \%)$ was observed in $1: 2(\mathrm{w} / \mathrm{v})$ concentration of Burmuda grass extract and the lowest $(76.50 \%)$ in the control. Germination percent of apparently healthy seeds was always found to be higher over farmers saved seed. The highest germination $(99.60 \%)$ of apparently healthy seeds was noted in 1:2 $(\mathrm{w} / \mathrm{v})$ concentration of Burmuda grass extract treated seeds and the lowest $(78.00 \%)$ in the control.

The incidence of Bipolaris sorokiniana in Burmuda grass extract treated wheat seeds was always higher in farmers saved seeds over apparently healthy seeds (Table 5). The incidence of Bipolaris sorokiniana on farmer's saved seed ranged from $16.50 \%$ to $43.00 \%$ in untreated control and 1:2 ( $\mathrm{w} / \mathrm{v})$ concentration of Burmuda grass extract treated seeds respectively. Similarly these two treatments resulted the highest (39.43\%) and the lowest (12.33\%) incidence of the fungus, respectively. It was found that apparently healthy seeds had comparatively lower incidence of the fungus over farmer's seed.

\subsection{Evaluation of Black cumin seeds extracts against Bipolaris sorokiniana}

The effects of Black cumin seed extract treated apparently healthy and farmer's saved wheat seeds germination and incidence of Bipolaris sorokiniana are present in Table 6. Germination (\%) of farmer's seed ranged from $76.50 \%$ to $83.17 \%$. The highest seed germination $(83.17 \%)$ was recorded in 1:2 $(\mathrm{w} / \mathrm{v})$ concentration of Black cumin seed extract and the lowest $(76.50 \%)$ in the control. Germination (\%) of apparently healthy seeds was found to be higher over farmer's seed. The highest germination (91.00\%) of apparently healthy seeds of wheat was noted in $1: 2(\mathrm{w} / \mathrm{v})$ concentration of Black cumin seed extract and the lowest $(78.00 \%)$ in the control. 
Indigenous plant extracts for suppressing Bipolaris sorokiniana

101

Table 4. Effect of seed treatment with Nut sedge grass extract on germination and incidence of Bipolaris sorokiniana of wheat.

\begin{tabular}{|c|c|c|c|c|c|}
\hline \multirow{2}{*}{ Treatments } & \multirow{2}{*}{ Concentration } & \multicolumn{2}{|c|}{$\%$ Germination } & \multicolumn{2}{|c|}{$\begin{array}{c}\% \text { Incidence of } \\
\text { Bipolaris sorokiniana }\end{array}$} \\
\hline & & $\begin{array}{c}\text { Farmer's } \\
\text { saved } \\
\text { seed }\end{array}$ & $\begin{array}{l}\text { Apparently } \\
\text { healthy } \\
\text { seed }\end{array}$ & $\begin{array}{c}\text { Farmer's } \\
\text { saved } \\
\text { seed }\end{array}$ & $\begin{array}{c}\text { Apparently } \\
\text { healthy } \\
\text { seed }\end{array}$ \\
\hline Untreated control & & $76.50 \mathrm{~d}$ & $78.00 \mathrm{~d}$ & $43.00 \mathrm{a}$ & $39.43 a$ \\
\hline Nut sedge rhizome extract & $1: 2\left({ }^{\mathrm{W}} / \mathrm{v}\right)$ & $93.00 \mathrm{a}$ & $98.00 \mathrm{a}$ & $19.00 \mathrm{~d}$ & $14.50 \mathrm{e}$ \\
\hline Nut sedge rhizome extract & $1: 4(\mathrm{w} / \mathrm{V})$ & $90.00 \mathrm{bc}$ & $98.00 \mathrm{a}$ & $20.33 d$ & $15.50 \mathrm{~d}$ \\
\hline Nut sedge rhizome extract & $1: 6\left({ }^{\mathrm{W}} / \mathrm{v}\right)$ & $91.00 \mathrm{~b}$ & $95.00 \mathrm{~b}$ & $23.00 \mathrm{c}$ & $20.50 \mathrm{c}$ \\
\hline Nut sedge rhizome extract & $1: 8(\mathrm{w} / \mathrm{V})$ & $89.17 \mathrm{c}$ & $91.00 \mathrm{c}$ & $26.50 \mathrm{~b}$ & $25.00 \mathrm{~b}$ \\
\hline $\operatorname{LSD}(\mathrm{P} \leq 0.05)$ & & 1.702 & 0.842 & 1.702 & 0.2147 \\
\hline
\end{tabular}

Table 5. Effect of seed treatment with Burmuda grass extract on germination and incidence of Bipolaris sorokiniana of wheat.

\begin{tabular}{|c|c|c|c|c|c|}
\hline \multirow{2}{*}{ Treatments } & \multirow{2}{*}{ Concentration } & \multicolumn{2}{|c|}{$\%$ Germination } & \multicolumn{2}{|c|}{$\begin{array}{c}\% \text { Incidence of } \\
\text { Bipolaris sorokiniana }\end{array}$} \\
\hline & & $\begin{array}{l}\text { Farmer's } \\
\text { saved } \\
\text { seed }\end{array}$ & $\begin{array}{l}\text { Apparently } \\
\text { healthy } \\
\text { seed }\end{array}$ & $\begin{array}{c}\text { Farmer's } \\
\text { saved } \\
\text { seed }\end{array}$ & $\begin{array}{l}\text { Apparently } \\
\text { healthy } \\
\text { seed }\end{array}$ \\
\hline Untreated control & & $76.50 \mathrm{~d}$ & $78.00 \mathrm{c}$ & $43.00 \mathrm{a}$ & $39.43 a$ \\
\hline Burmuda grass extract & $1: 2\left({ }^{\mathrm{W}} / \mathrm{v}\right)$ & $95.83 \mathrm{a}$ & $99.60 \mathrm{a}$ & $16.50 \mathrm{e}$ & $12.33 \mathrm{e}$ \\
\hline Burmuda grass extract & $1: 4\left({ }^{\mathrm{W}} / \mathrm{v}\right)$ & $95.50 \mathrm{a}$ & $99.53 \mathrm{a}$ & $19.50 \mathrm{~d}$ & $15.57 \mathrm{~d}$ \\
\hline Burmuda grass extract & $1: 6(\mathrm{w} / \mathrm{v})$ & $92.50 \mathrm{~b}$ & $99.40 \mathrm{~b}$ & $23.17 \mathrm{c}$ & $17.50 \mathrm{c}$ \\
\hline Burmuda grass extract & $1: 8\left({ }^{\mathrm{W}} / \mathrm{v}\right)$ & $90.50 \mathrm{c}$ & $98.27 b$ & $24.40 \mathrm{~b}$ & $18.57 \mathrm{~b}$ \\
\hline $\operatorname{LSD}(\mathrm{P} \leq 0.05)$ & & 0.4874 & 1.210 & 0.4874 & 0.3622 \\
\hline
\end{tabular}


Table 6. Effect of seed treatment with Black cumin seed extract on germination and incidence of Bipolaris sorokiniana of wheat.

\begin{tabular}{|c|c|c|c|c|c|}
\hline \multirow{2}{*}{ Treatments } & \multirow{2}{*}{ Concentration } & \multicolumn{2}{|c|}{$\%$ Germination } & \multicolumn{2}{|c|}{$\begin{array}{c}\% \text { Incidence of } \\
\text { Bipolaris sorokiniana }\end{array}$} \\
\hline & & $\begin{array}{c}\text { Farmer's } \\
\text { saved } \\
\text { seed }\end{array}$ & $\begin{array}{l}\text { Apparently } \\
\text { healthy } \\
\text { seed }\end{array}$ & $\begin{array}{l}\text { Farmer's } \\
\text { saved } \\
\text { seed }\end{array}$ & $\begin{array}{l}\text { Apparently } \\
\text { healthy } \\
\text { seed }\end{array}$ \\
\hline Untreated control & & $76.50 \mathrm{~d}$ & $78.00 \mathrm{~d}$ & $43.00 \mathrm{a}$ & $39.43 a$ \\
\hline Black cumin seed extract & $1: 2\left({ }^{\mathrm{w}} / \mathrm{v}\right)$ & $83.17 \mathrm{a}$ & $91.00 \mathrm{a}$ & $27.17 d$ & $15.20 \mathrm{~d}$ \\
\hline Black cumin seed extract & $1: 4\left({ }^{\mathrm{W}} / \mathrm{V}\right)$ & $82.17 b$ & $85.17 b$ & $30.17 \mathrm{c}$ & $23.00 \mathrm{e}$ \\
\hline Black cumin seed extract & $1: 6\left({ }^{\mathrm{W}} / \mathrm{v}\right)$ & $82.50 \mathrm{~b}$ & $84.17 \mathrm{c}$ & $31.50 \mathrm{c}$ & $26.50 \mathrm{c}$ \\
\hline Black cumin seed extract & $1: 8\left({ }^{\mathrm{W}} / \mathrm{v}\right)$ & $81.00 \mathrm{c}$ & $84.50 \mathrm{c}$ & $34.50 \mathrm{~b}$ & $30.50 \mathrm{~b}$ \\
\hline LSD $(\mathrm{P} \leq 0.05)$ & & 0.3622 & 0.421 & 1.670 & 0.2063 \\
\hline
\end{tabular}

The incidence of Bipolaris sorokiniana on Black cumin seed extract treated wheat seeds was always higher in farmers saved seeds over apparently healthy seeds (Table 6). The incidence of Bipolaris sorokiniana on farmer's saved seed ranged from $27.17 \%$ to $43.00 \%$, the highest and the lowest incedence was recorded in untreated control and 1:2 $(\mathrm{W} / \mathrm{v})$ concentration of Black cumin seed extract treated seeds. Similarly these two treatments resulted in the highest (39.43\%) and the lowest $(15.20 \%)$ incidence of the fungus, respectively in apparently healthy seeds. It was found that apparently healthy seeds had comparatively lower incidence of the fungus over the farmer's seed.

Seed treatment with plant extracts had profound effect on seed germination and incidence of Bipolaris sorokiniana. The present findings agree with the findings of Rahman (2007) who found that botanicals have strong effect against Bipolaris sorokiniana. Islam (2006) also reported that Kalizira, Neem, Onion and Zinger extracts significantly reduced the incidence of
Bipolaris sorokiniana on wheat seeds. The present findings are also supported by Alice and Rao (1987), Fakir and Khan (1992), Khan and Kumar (1992), Hossain and Schlosser (1993), Khan and Fakir (1995) and Hossain et al. (1997). Ashrafuzzaman and Hossain (1992) reported that Neem extract is effective against Bipolaris sorokiniana and inhibited the growth of the fungus and also reduced its pathogenecity on wheat leaves. Hossain and Schlosser (1993) reported that germination rate of wheat seeds increased while treated with extract of Neem seed and Neem oil cake. Hossain et al. (2005) reported that Neem extract reduced the incidence of Bipolaris sorokiniana significantly and increased seed germination. They also found that out of six plant extracts, Neem extract was superior followed by garlic, Bishkatali and Vatpata. Alice and Rao (1987) evaluated plant extracts against seed borne infection of fungi and found increased germination of the treated seeds. Khan and Kumar (1992) also observed the antifungal activity of leaf extracts of Neem against seed mycoflora of wheat. They found 
remarkable reduction of seed mycoflora and increased seed germination of treated seeds.

\section{Conclusions}

On the basis of the present findings a comparative evaluation of the observed best concentrations of the five plant extracts may be undertaken for final recommendation.

\section{Acknowledgements}

The authors gratefully acknowledge the financial support by the University Grants Commission of Bangladesh to conduct the work.

\section{References}

Alice, A. and Rao, A. V. 1987. Antifungal effect of plant extracts on Drechslera oryzae in rice. Res. News Letter. 12(2): 28.

Ashrafuzzaman, H. and Hossain, I. 1992. Antifungal activity of crude extracts of plans against Rhizoctonia solani and Bipolaris sorokiniana. Proc. BAU. Research Progress 6: 188-192.

Assadi, P. and Behroozin, M. 1987. The effect of bulb extracts of onion and garlic on the mycelial growth of Fusarium spp. Sclerotium cepivorum Iranian Journal of Plant Pathology, 23(1-4): 1-3.

Azhar, H., Meah, M. B., Mamotaz, M. A., Mohammad, P., Haque, N. R. and Akand, I. 1972. Research progress on alien variation into Bangladesh wheat. Annual wheat news letter. CIMMYT. 38:60-61.

BBS (Bangladesh Bureau of Statistics), 2006. Monthly Statistical Bulletin. Statistics Division. Ministry of Planning. Government of the Peoples Republic of Bangladesh. Dhaka, 57p.

Booth, C. (1971). The genus Fusarium. Commonwealth Mycol. Inst. Kew, Surrey, England. 231p.

Ellis, M. B. 1971. Dematiaceous Hyphomycetes.
Commonwealth Mycol. Inst. Kew, Surrey, England, 608. Proceeding of the International Symposium, Sept. 24-28, $148 \mathrm{p}$.

Fakir, G.A. 1988. Report on investigation of black point disease of wheat in Bangladesh. Seed Pathology Laboratory. Dept. of Plant Pathology, Bangladesh Agricultural University, Mymensingh, 36p.

Fakir, G. A. and Khan, A. A. 1992. Control of some selected seed-borne fungal pathogen of jute by Effect of seed treatment with garlic extract. Proc. BAU, Research Progress. 6:176-180.

FAO (Food and Agricultural Organization of the United Nations). 1997. Production year book. Food and Agricultural Organization of the United Nations, Italy. Rome, 62p.

Hossain, I. and Azad, A. K. 1992. Bipolaris sorokiniana, its reaction and effect on yield of wheat. Progressive Agriculture, 5(2): 63-69.

Hossain, I. and Schlosser, E. 1993. Control of Bipolaris sorokiniana in wheat with Neem extracts. Bangladesh Journal of Microbiology, 10(1): 39-42.

Hossain, I., Mahamud, H. and Ashrafuzzaman, H. 1997. Effect of plant extracts on fungi (Bipolaris sorokiniana and Alternaria solani) and okra mosaic disease. Ecoprint, 4(1):35-42.

Hossain. M. M., Khalequzzaman K. M., Aminuzzaman F. M., Mollah, M. R. A. and Rahman, G. M. M. 2005. Effect of Plant Extract on the Incidence of SeedBorne Fungi of Wheat. Journal of Agriculture and Rural Development, 3 (1 and 2): 39-43.

Islam, M. A. 2006. Efficacy of Selected Plant Extracts on Leaf Spot (Bipolaris 
sorokiniana) and Grain Yield of Wheat. MS. Thesis. Department of Plant Pathology, SAU, Dhaka. 6p

ISTA. 1999. International Rules for Seed Testing. Seed Science and Technology, 27, the Supplement, 333p.

Khan, M. I. and Kumar, R. 1992. Antifungal activity of leaf extracts of Neem on seed mycoflora of wheat. Abstract of Indian Journal of Seed 15(7): 299.

Khan, A. A. and Fakir, G. A. 1995. Effect of seed treatment with garlic extract to control seed-borne pathogen of jute. Bangladesh Journal of Plant Pathology, 11(1-2): 15-19.

Majumder, M. 1991. Crops of Eastern India. West Bengal stage Book Board. Arg. Mansion (8th floor). C/A, Rata Subodh Mallik square, Calcutta. $85 \mathrm{p}$.

Miah, A., Ahmed, M. U., Sharma, N., Ali, R. and Miah, S. A. 1990. Antifungal activity of some plant extracts. Bangladesh Journal of Botany, 19(1): 5-20.

Rahman, M.M. 2007. Efficacy of seed treatment with plant extracts on leaf blight (Bipolaris sorokiniana) development and yield of wheat. MS Thesis. Department of Plant Pathology, SAU, Dhaka. 6p

Razzaque, M. A., Suffin, M. A. and Badruddin, M. 1992. Wheat in the national economy in Bangladesh. In advances in the crop science, Proceeding of the first biennial Conference of the Crop Science Society of Bangladesh, 18-20 January, 1992, 13-25pp.

Suratuzzaman, M. 1995. Studies on the seedborne fungi of soybean and its control, M. Sc. Ag. Thesis. Dept. of Plant Pathol. BAU, Mymensingh. Bangladesh, 58p. 